\title{
Penerapan Sistem Absensi Sekolah Menggunakan Fingerprint Terintegrasi Dengan Smartphone Android
}

\author{
A Sumarudin ${ }^{1 *}$, Willy Permana $P^{2 *}$, Adi Suheryadi ${ }^{3 *}$, Kikis Maulana ${ }^{4 *}$, Noufal Ibrahim ${ }^{5 *}$ \\ ${ }^{*}$ Jurusan Teknik Informatika, Politeknik Negeri Indramayu \\ $\underline{\text { shumaru@polindra.ac.id }}^{1}$, willy@polindra.ac.id ${ }^{2}$, adisuheryadi@polindra.ac.id ${ }^{3}, \underline{\text { kikismaulana1902@gmail.com }}^{4}$, \\ noufalibrahim8598@gmail.com ${ }^{5}$
}

\begin{tabular}{l}
\hline Article Info \\
\hline Article history: \\
Received 07-12-2018 \\
Revised 26-03-2019 \\
Accepted 07-05-2019 \\
\hline
\end{tabular}

\section{Keyword:}

fingerprint,

web service,

$S O A P$,

$X M L$,

android.

\begin{abstract}
The need of student attendance information in schools is a major factor in success of the academic process. Often there are validation and identification errors in the student attendance process (human error or manipulation process) as well as the slowness of information obtained, since the attendance is recorded manually in each class. This has an impact on success of the academic process directly and the community at large. Because the importance of attendance information, various studies have offered the system in the process of student attendance, with various technologies. One popular technology and believed to be validating and identifying well is the fingerprint. Therefore, this paper proposes the introduction of attendance system in schools by utilizing fingerprint technology integrated with android smartphone so that information can be delivered quickly. This study use Fingerprint $\mathrm{X}-100 \mathrm{C}$ as a means of identification of student data at the time of absence then the attendance data will be sent to the system database by SOAP (Simple Object Access Protocol) Web Service. The system will validate and transmit that information on the android Smartphone via the newly created XML Service. The success rate of this system in processing absence reach around $90.47 \%$ with delay time of sending information $0.0024 \mathrm{~s}$ This system has been tested and applied to SMK $\mathrm{N} 1$ Indramayu.
\end{abstract}

Copyright (C) 2019 Journal of Applied Informatics and Computing. All rights reserved.

\section{Pendahuluan}

Perkembangan teknologi semakin pesat, menjadikan informasi semakin cepat didapatkan. Hal ini didorong oleh perkembangan teknologi yang sampai pada masyarakat. Hampir setiap lapisan masyarakat sekarang ini memiliki smartphone. Dengan teknologi Mobile yang dikenal dengan smartphone ini, dapat melakukan berbagai aktifitas diantaranya transaksi perbankan, mencari informasi di internet bahkan kegiatan-kegiatan yang lain dan aktifitas ini bisa dilakukan dimana saja, kapan saja tanpa harus terhalang waktu dan tempat. Teknologi telpon pintar sudah bukan rahasia umum lagi, aplikasi yang wajib di Install pada Smartphone yaitu aplikasi whatsapp, line, BBM, aplikasiaplikasi ini mempermudah dalam bertukar informasi dalam waktu yang sangat singkat.

Perkembangan teknologi dan informasi tersebut dialami diberbagai bidang salah satunya adalah pendidikan [5]. Penerapan teknologi informasi dalam bidang pendidikan berupa pembelajaran jarak jauh berbasis website juga tidak lepas mewarnai dunia pendidikan saat ini [6]. Penerapan ini bertujuan untuk penyebaran informasi sehingga dapat meningkatkan mutu pembelajaran di sekolah. Konsep pembelajaran dengan pengembangan teknologi informasi ini memberikan konsep bahwa guru bukan hanya sebagai sumber pembelajaran tetapi menjadi partner mitra belajar siswa. Penerapan smart-school ini diharapkan merupakan efektivitas dan efisiensi pelaksanaan proses pendidikan di Indonesia. Penerapan smart-school sudah dilakuakn di skaci-iss merupakan kerjasama tim csc-itb dengan SKACI Fundation untuk menerapkan sekolah berbasis teknologi.

Dalam meningkatkan mutu pendidikan diindonesia, hal yang sangat penting untuk diperhatikan diantaranya adalah tingkat kehadiran siswa disekolah. Karena kualitas penyerapan materi pembelajaran dinilai berbanding lurus dengan kehadiran siswa disekolah. Data dari data statistik Sekolah Menengah Kejuruan (SMK) 2015-2016 menunjukkan di provinsi jawa barat sebesar 16.669 siswa mengalami putus sekolah [5]. Dari data tersebut salah satu faktor eksternal yang mempengaruhi terjadinya putus sekolah adalah pergaulan dan kurangnya pengawasan baik dari orang tua maupun sekolah. Hal ini memunculkan perhatiaan khusus 
bagi para peneliti untuk dapat meningkatkan angka kehadiran siswa disekolah dengan mengusulkan berbagai tekonologi [3, $7,9]$. Salah satu teknologi yang dipercaya dalam hal validasi kehadiran adalah menggunakan fingerprint [1].

Dengan demikian kami mencoba untuk menerapkan suatu teknologi monitoring yang dapat dimanfaatkan oleh orang tua dan sekolah dalam mengawasi kehadiran siswa di sekolahnya, dimana teknologi tersebut mengintegrasikan antara perangkat absensi, kemudahan monitoring dengan smartphone secara real-time dan teknologi informasi yang ringan dan cepat melalui website, sebagaimana ditunjukan pada gambar 2 . Diharapkan menejemen siswa dapat dikelola berbasis teknologi informasi yang dapat memberikan data awal ketika terjadi siswa yang beramasalah terhadapat kehadiran. Selain itu juga, absesni sangat penting sebagai indikator kedisiplinan siswa dan guru yang dibutuhkan untuk analisis pihak menejemen sekolah dan guru kelas serta wali murid tentang perkembangan siswanya di sekolah.

\section{Metode Penelitian}

Tahapan penelitian dalam pembuatan sistem ini adalah dengan merujuk pada pendekatan software testing yang biasa dikenal dengan SDLC (Software Development Life Cycle) [4]. SDLC ini memiliki beberapa tahap penting yaitu seperti yang ditunjukan pada gambar 1. Dalam penelitian ini menggunakan metode pengembangan perangkat lunak (SDLC) yaitu waterfall.

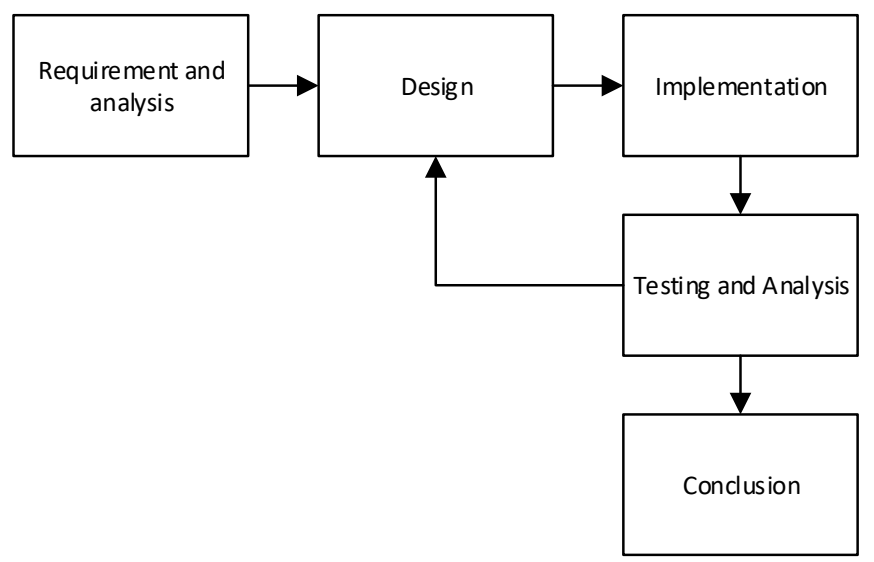

Gambar 1. Software Development Life Cycle

Dalam tahapannya terdiri dari requirement dan analisis tahap ini digunakan untuk mencari kebutuhan dalam membangun sistem. Tahap ini dilakukan wawancara langsung pada narasumber atau pelaku dari sistem yang akan dibuat. Kemudian tahap selanjutnya adalah mendesain dan mengimplementasikan sistem. Desain yang dibuat dapat dilihat pada gambar 2 dan 3. Dalam implementasi pengkodeaan dilakukan dengan membuat program pada platform android dan website, serta API yang berfungsi melayani service untuk client dari aplikasi android. Tahap selanjutnya adalah ujicoba dan analisis, jika terdapat kekurangan maka kembali pada tahap implementasi dan perbaikan namun jika telah sesuai dengan requirement yang ada maka masuklah pada tahap conclusion yaitu memberikan kesimpulan akhir dari sistem tersebut.

Konsep dasar dari sistem ini merupakan teknologi yang mengintegrasi komponen - komponen penting dalam sistem sekolah. Dalam penerapan sistem ini mengintegrasikan beberapa device diantaranya komputer dan smartphone, dimana device tersebut akan mengakses dan mengolah data pada server yang telah terdapat didalamnya sistem absensi. Sistem absensi ini mendapat input dari fingerprint yang telah terpasang dan dapat diakses oleh siswa, gambaran global dari sistem absensi ini dapat dilihat pada gambar 2 .

Secara umum sistem yang akan dibuat dapat dilihat pada gambar 2, dimana terdapat empat pengguna utama yaitu orang tua/wali murid, siswa, guru dan petugas sekolah. Media dalam mengakses sistem ini terbagi menjadi dua diantaranya melalui aplikasi moble (android) dan melalui website dapat diakses baik dari komputer maupun smartphone. Server digunakan untuk melayani request dari pengguna dan melaporkan kehadiran siswa yang diinput langsung dari fingerprint.

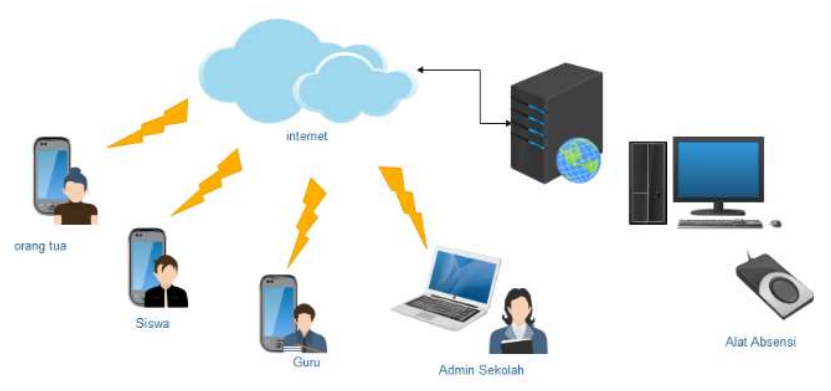

Gambar 2. Global Arsitektur Sistem Absensi yang diusulkan

Perancangan sistem absensi terintegrasi smartphone ditunjukan pada gambar 3. Orang tua siswa akan mendapatkan informasi kehadiran anaknya secara real-time melalui smartphone androidnya. Selain itu orangtua pun memiliki fasilitas untuk mengajukan permohonan izin ketidak hadiran anaknya dengan menggunggah surat keterangan. Selain orang tua petugas administrasi mendapatan kemudahan dalam rekapitulasi kehadiran siswa disekolah yang dilakukan secara otomatis melalui sistem yang ada.

Proses yang dilakukan oleh sistem sebagaimana yang ditunjukan pada gambar 3, yaitu siswa pada saat masuk sekolah akan melakukan absensi dmenggunakan alat fingerprint. Setelah sistem dapat memfalidasi sidik jari siswa, kemudian sistem akan mengirimkan notifikasi pada smartphone baik siswa maupun orang tua secara real-time mmelalui aplikasi Mobile-Attendance Fingerprint (M-Afi). Sedangkan petugas administrasi sekolah dapat mengecek kehadiran siswa secara berkala melalui website, termasuk 
didalamnya apabila siswa tersebut berhalangan masuk dengan keterangan yang dikirimkan oleh orang tua melalui aplikasi mobile M-AFi.

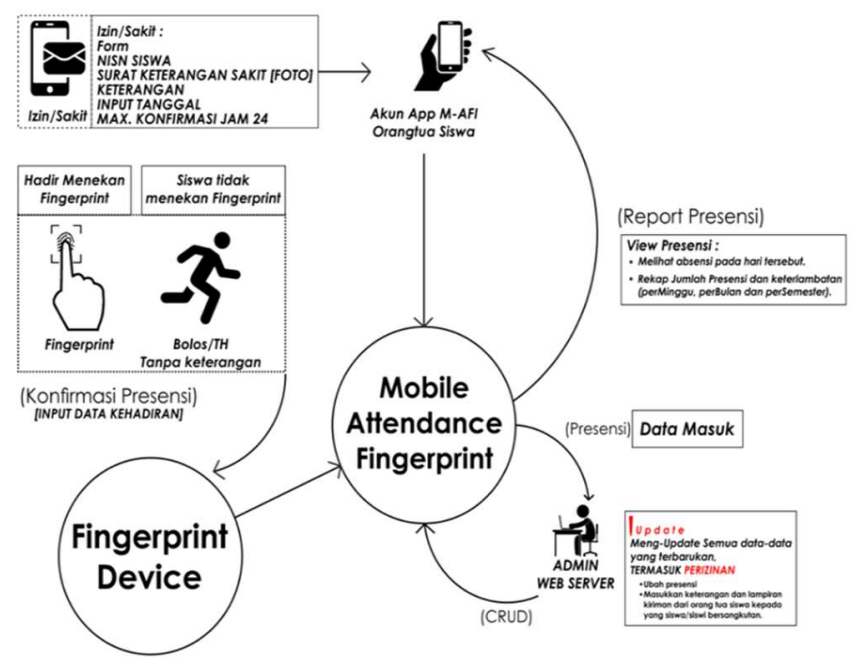

Gambar 3. Global Desain Sistem Absensi Terintegrasi Smartphone

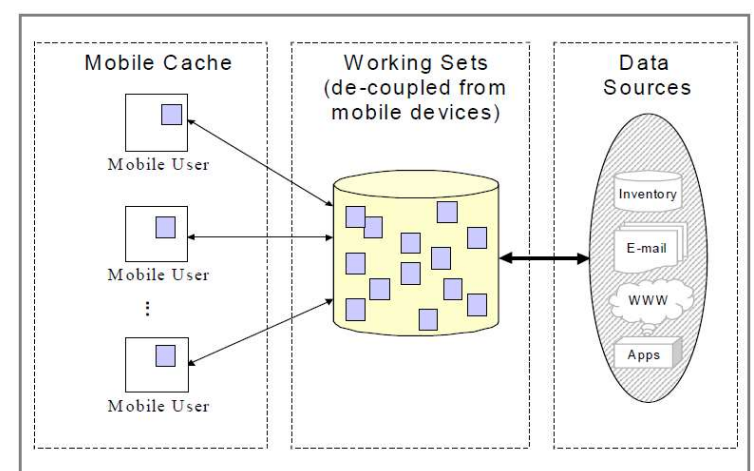

Gambar 4. Skema Aplikasi Dengan Tiga Level Arsitektur [8]

Aplikasi dari smartphone android dirancang dengan konsep three tier architecture application [8]. Aplikasi client tidak berhubungan langsung dengan basis data (database), sehingga dalam mengkases data membutuhkan suatu service yang melayani proses pengambilan data tersebut, skema aplikasi dengan tiga level arsitektur dapat dilihat pada gambar 4. Dalam skema aplikasi tiga level arsitektur ini terbagi menjadi tiga bagian yaitu mobile user berhubungan langsung dengan persentation part atau user interface, kemudian bagian kedua adalah working sets atau layanan-layanan yang disediakan oleh aplikasi dalam hal ini berisi tentang businnes logic dari fitur atau layanan. Working sets diletakan pada server aplikasi, pada perancangan sistem abesensi terintegrasi ini menggunakan SOAP Web Service [2].

Proses utama dalam aplikasi smartphone android terdiri dari realtime monitoring absensi, rekap absensi dan permohonan izin ketidak hadiran siswa. Proses absensi realtime monitoring absensi dan rekap absensi memiliki sequence diagram seperti yang ditunjukan pada gambar 5, sedangkan sequence diagram untuk pengajuan izin ketidak hadiran ditunjukan pada gambar 6 .

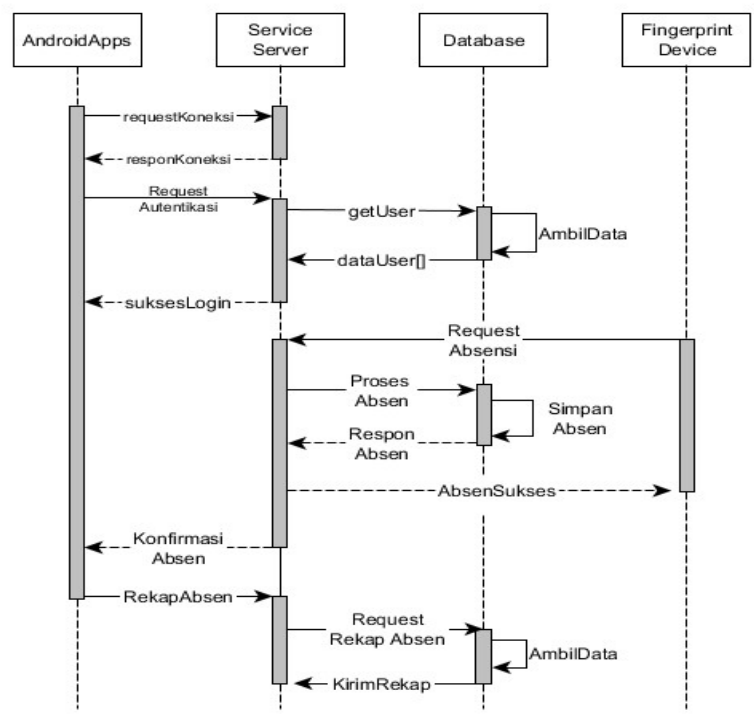

Gambar 5. Squence diagram proses absensi

Service yang digunakan dalam menyediakan layanan pada mobile aplikasi menggunakan web service dengan teknologi SOAP Web service. Fitur atau fungsi utama pada aplikasi mobile M-AFi ini adalah proses real-time absensi dan permohonan izin. Proses absensi ditunjukan pada gambar 5, terdapat service server yang bertugas melayani request data dari proses real-time absensi. Pada saat proses absensi dilakukan maka pertama fingerprint akan mendapatkan triger dari siswa yang melakukan absensi, kemidan server akan memantau request dari absensi siswa tersebut dan kemudian mengakses data dari fingerprint dan menyimpannya ke dalam database. Setelah tersimpan pada database proses selanjutnya adalah server menjalankan service untuk memberikan notifikasi kehadiran dari siswa pada aplikasi M-AFi. Aplikasi mobile $\mathrm{M}-\mathrm{AFi}$ ini pula dapat mengirimkan request berupa rekap absensi dari siswa tersebut.

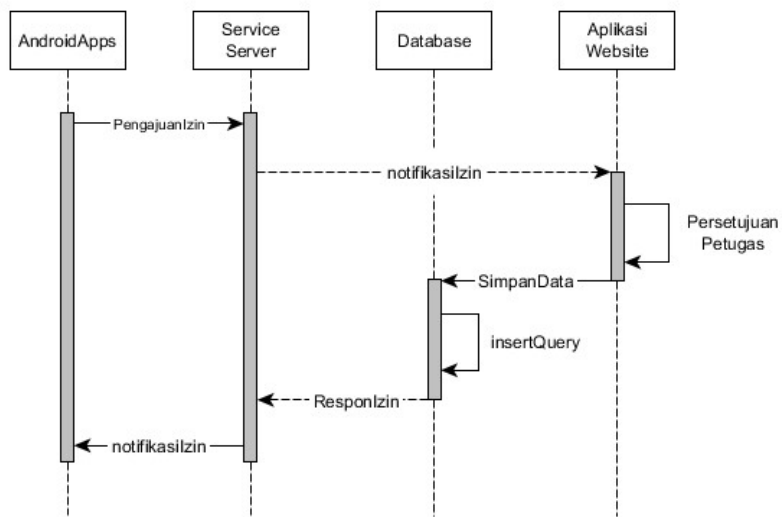

Gambar 6. Sequence diagram permohonan izin 
Sedangkan pada proses permohonan izin, request pertama kali dilakukan oleh aplikasi mobile M-AFi dengan login orang tua. Setelah service mendapatkan request permohonan izin tersebut, maka service akan mengirimkan notifikasi pada website admin dan kemudian data disimpan pada database. Admin dapat melihat request tersebut melalui website dan melakukan verifikasi surat izin yang diunggah oleh orang tua melalui aplikasi mobile $\mathrm{M}-\mathrm{AFi}$.

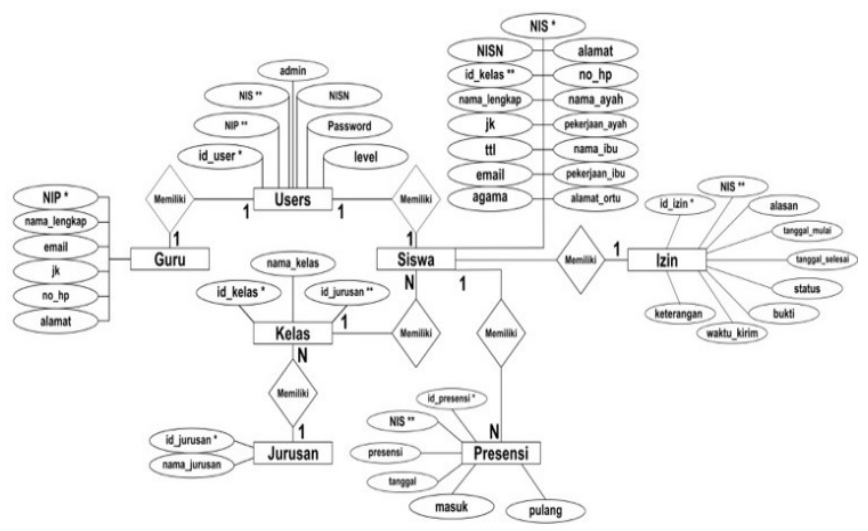

Gambar 7. Entity relation diagram

Database dalam sistem ini dibentuk dalam tujuh tabel yang ditunjukan pada gamabr 7 . Ketujuh tabel database tersebut meliputi tabel user, guru, siswa, izin, kelas, kelas jurusan dan presensi. Tabel siswa dalam database tersebut merupakan tabel utama, dimana setiap tabel lainnya akan terhubung secara langsung atau tidak langsung pada tabel tersebut. Tabel user memuat informasi penting terkait username dan password untuk mengakses aplikasi baik aplikasi smartphone maupun website. Terdapat dua tabel yang terhubung langsung pada tabel user secara independent yaitu tabel guru dan siswa.

\section{HASIL DAN PEMBAHASAN}

Dalam hasil dan pembahasan akan dibagi menjadi dua bagaian yaitu pembahasan kualitatif dan kuantitatif. Dimana pembahasan kualitatif berkenaan dengan hasil integrasi aplikasi yang telah diimplementasikan, sedangkan pembahasan kuatitatif berkenaan dengan analisis hasil percabaan dan saran pengembangan, terkait sistem absensi sekolah terintegrasi.

Sistem absensi sekolah terintegrasi ini, terdiri dari dua jenis aplikasi yaitu aplikasi smartphone dan aplikasi website. Aplikasi smartphone digunakan untuk monitoring kehadiran siswa oleh orang tua, guru dan notifikasi presensi pada siswa. Aplikasi tersebut dinamakan Aplikasi Mobile-Attendance Fingerprint (M-AFi). Semua fitur dan fungsi dari aplikasi MAFi telah diujikan dalam ujicoba fungsionalitas aplikasi. Hasil aplikasi ini ditunjukan pada gambar 8, digunakan oleh orang tua, guru, maupun siswa. Aplikasi website juga telah diujikan dalam uji fungsionalitas aplikasi, sampel hasil aplikasi website ditunjukan pada gambar 9 .

Hasil pengujian absensi dapat dilihat pada tabel 1. Dari data tersebut dilihat dapat dilihat waktu tunggu tercepat dalam proses absensi secara keseluruhan adalah 20 detik dan yang terlama sekitar 15 menit. Hal ini dikarenakan proses absensi sidik jari dilakukan secara bergantian. Adapun waktu tunggu yang lama sampai 15 menit hal ini dikarenakan keterlambatan siswa dalam absensi masuk.

Delay waktu pengiriman informasi absensi menuju aplikasi smartphone itu sendiri sekitar $2.4 \mathrm{~ms}$ dilihat dari notifikasi yang berhasil dikirimkan oleh server pada aplikasi mobile MAFi dengan tingkat keberhasilan sistem mencapai $90.47 \%$, tingkat keberhasilan ini diukur dengan menggunakan recall dimana jumlah keberhasilan notifikasi real-time pada smartphone, dibandingkan dengan seluruh pengujian absensi yang dilakukan oleh siswa.

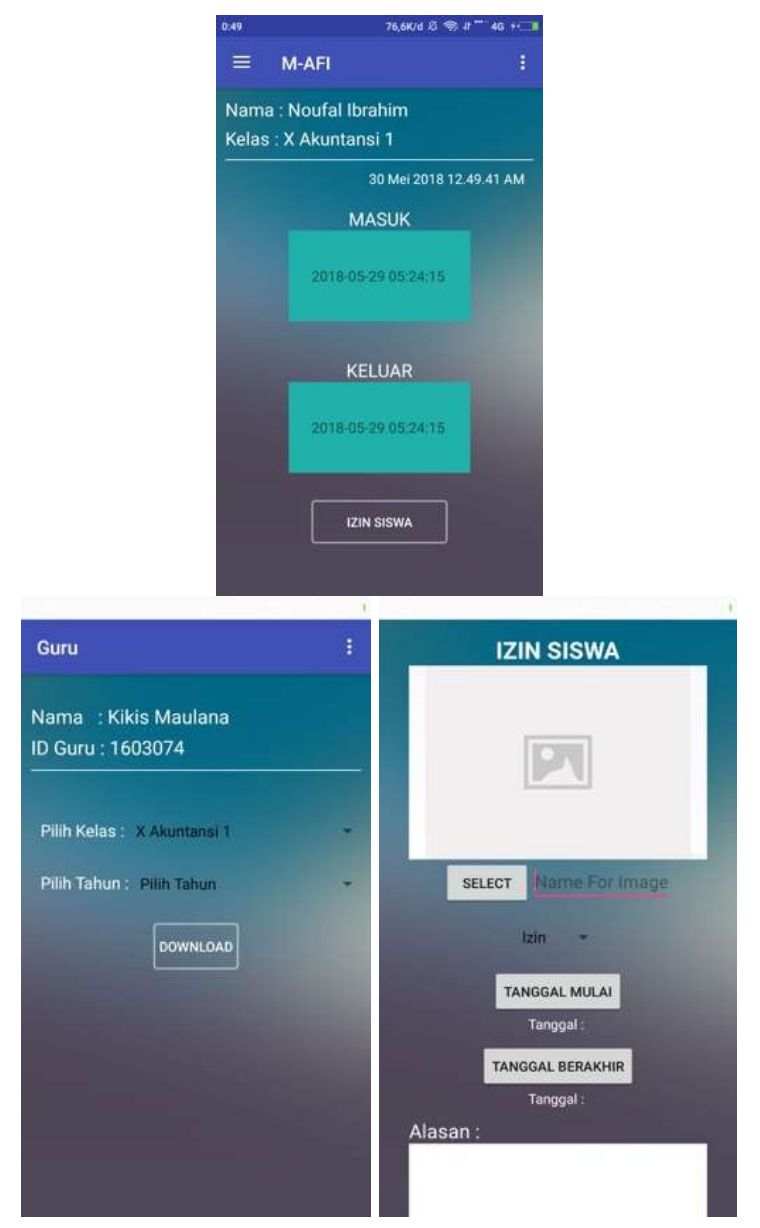

Gambar 8. Tampilan aplikasi smartphone 


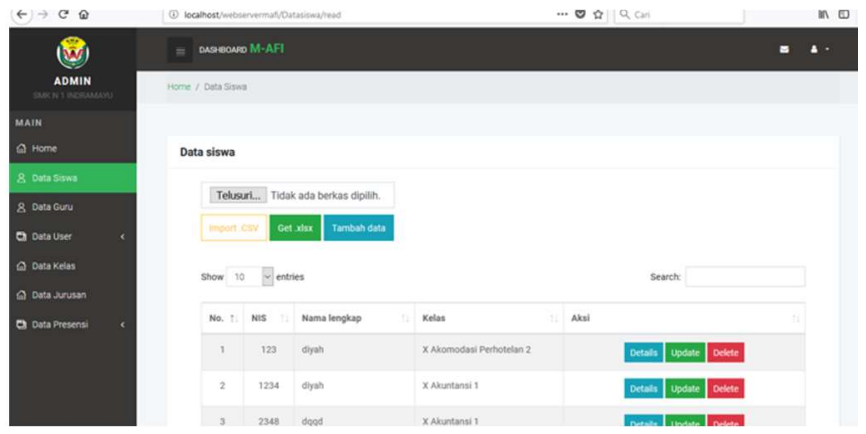

Gambar 9. Tampilan aplikasi website

TABEL 1

HASIL REKAPITULASI ABSENSI

\begin{tabular}{|c|c|c|c|c|}
\hline Kehadiran & Tanggal & Waktu & $\begin{array}{c}\text { Ketidak } \\
\text { Hadiran }\end{array}$ & $\begin{array}{c}\text { Delay } \\
\text { Absen }\end{array}$ \\
\hline Hadir & $6 / 26 / 2018$ & $7: 00: 38$ & NULL & $0: 00: 40$ \\
\hline Hadir & $6 / 26 / 2018$ & $7: 01: 18$ & NULL & $0: 00: 43$ \\
\hline Hadir & $6 / 26 / 2018$ & $7: 02: 01$ & NULL & $0: 01: 00$ \\
\hline Hadir & $6 / 26 / 2018$ & $7: 03: 01$ & NULL & $0: 00: 46$ \\
\hline Hadir & $6 / 26 / 2018$ & $7: 03: 47$ & NULL & $0: 01: 44$ \\
\hline Hadir & $6 / 26 / 2018$ & $7: 05: 31$ & NULL & $0: 00: 48$ \\
\hline Hadir & $6 / 26 / 2018$ & $7: 06: 19$ & NULL & $0: 01: 18$ \\
\hline Hadir & $6 / 26 / 2018$ & $7: 07: 37$ & NULL & $0: 00: 22$ \\
\hline Hadir & $6 / 26 / 2018$ & $7: 07: 59$ & NULL & $0: 01: 54$ \\
\hline Hadir & $6 / 26 / 2018$ & $7: 09: 53$ & NULL & $0: 01: 30$ \\
\hline Hadir & $6 / 26 / 2018$ & $7: 11: 23$ & NULL & $0: 01: 41$ \\
\hline Hadir & $6 / 26 / 2018$ & $7: 13: 04$ & NULL & $0: 00: 47$ \\
\hline Hadir & $6 / 26 / 2018$ & $7: 13: 51$ & NULL & $0: 02: 00$ \\
\hline Hadir & $6 / 26 / 2018$ & $7: 15: 51$ & NULL & $0: 00: 20$ \\
\hline Hadir & $6 / 26 / 2018$ & $7: 16: 11$ & NULL & $0: 00: 58$ \\
\hline
\end{tabular}

\section{KESIMPULAN}

Aplikasi Mobile-Attendace Fingerprint (M-AFi) adalah salah satu aplikasi absensi siswa yang sangat penting bagi sekolah yang dapat memberikan kemudahan secara efektif untuk melakukan monitoring kehadiran siswa. Dengan adanya aplikasi ini guru dan orang tua mendapatkan kemudahan dalam memantau absensi sekolah. Dari hasil percobaan dan penggunaan aplikasi ini didapatkan akurasi recall absensi mencapai $90.47 \%$ dengan delay waktu pengiriman informasi sekitar 2,4 ms. Capaian keberhasilan absensi dengan real-time notifikasi dan delay pengiriman notifikasi menjadi fokus perhatian pada penelitian ini, karena akan berpengaruh langsung dengan jumlah pengguna dalam satu sekolah. Diharapkan pada saat penggunaan sistem ini sekolah dapat menyediakan lebih dari satu fingerprint device.

\section{UCAPAN TERIMA KASIH}

Terimakasih kepada Politeknik Negeri Indramayu.

\section{DAFTAR PUSTAKA}

[1] Alfien S. Rintjap, S. R. (2014). Aplikasi Absensi Siswa Menggunakan Sidik Jari Di Sekolah Menengah Atas Negeri 9 Manado. Jurnal Teknik Elektro Dan Komputer.

[2] D. Box, D. E. (2000). Simple Object Access Protocol (Soap) 1.1. W3c Note.

[3] Eko Budi Setiawan, B. K. (2015). Perancangan Sistem Absensi Kehadiran Perkuliahan Dengan Menggunakan Radio Frequency Identification (Rfid). Jurnal Coreit, Vol.1, No.2, Hal.44-49.

[4] Everett, G. D., \& Everett, G. D. (2007). Software Testing : Testing Across The Entire Testing Across The Entire. Canada: Wiley.

[5] K.Pendidikan, D. J. (2016). Sekolah Menengah Kejuruan. Bandung: Kemendikbud.

[6] Munir. (2009). Pembelajaran Jarak Jauh Berbasis Teknologi Informasi Dan Komunikasi. Bandung: Alfabeta.

[7] Ndri Neforawati, M. I. (2015). Rancang Bangun Aplikasi Sistem Informasi Monitoring Absensi Mahasiswa Politeknik Negeri Jakarta Menggunakan Teknologi Nfc Pada Android. Jurnal Poli Teknologi, Vol.14, No.2.

[8] S. Helal, J. H. (2001). A Three-Tier Architecture For Ubiquitous Data Access. International Conference On Computer Systems And Applications (Pp. 177-180). Beirut: Proceedings Of The First Acs/Ieee.

[9] Sri Hartati, A. I. (2018). Pengembangan Sistem Aplikasi Sms Gateway Sebagai Media Penyampaian Data Kehadiaran Siswa Pada Orang Tua. Jurnal Teknik Informatika Dan Sistem Informasi, 187-193 